\title{
Eucalypt pulp yield QTL from Raiz as compared to the literature
}

\author{
Cristina MP Marques ${ }^{1 *}$, Victor J Carocha², Carla Ribeiro ${ }^{3}$, Fátima Cunha ${ }^{1}$, António Mendes de Sousa ${ }^{1}$, \\ José A Araújo ${ }^{1}$, João Costa e Silva ${ }^{4}$, José Carlos Rodrigues ${ }^{5}$, Ana Freitas ${ }^{6}$, Ana M Pires ${ }^{6}$, Gabriel Dehon Rezende \\ From IUFRO Tree Biotechnology Conference 2011: From Genomes to Integration and Delivery \\ Arraial d Ajuda, Bahia, Brazil. 26 June - 2 July 2011
}

\section{Background}

RAIZ is a Portuguese private non-profit research institute owned by the Pulp \& Paper Portucel Soporcel Group (http://www.raiz-iifp.pt). RAIZ E. globulus genetic improvement program is managed in order to generate trees with increased economic value, through gains in forest productivity and wood properties. Molecular markers have been used for clonal identification and genetic diversity management in the program since 1990 . Moreover, RAIZ has been engaged in a longer term genomics project aiming to identify quantitative trait loci (QTL) for wood properties. The ability to detect QTL depends on sample size, genetic background, environment and genetic interactions. Most importantly, the ability to use detected QTL depends on their adequate map location and the identification of the molecular variation behind them. This in turn is determined by linkage map quality, the choice of phenotypes and the precision of phenotyping. There are many reports in the literature on QTL detection for economically important traits in Eucalyptus, but very few present data on QTL verification (at the statistical and/or biological levels). We illustrate the importance of this issue for pulp yield related traits by comparing available results from QTL mapping studies in the literature with those obtained from a QTL detection and verification experiment pursued by RAIZ.

\section{Methods}

An $F_{1}$ full-sib family with 361 progeny from an intraspecific E. globulus cross was planted in a field trial and phenotyped (at age $4_{1 / 2}$ years) for pulp yield using near infrared spectroscopy. Phenotypic data was adjusted for spatial variation in the field trial using a first-order

\footnotetext{
* Correspondence: cristina.marques@portucelsoporcel.com

'RAIZ, Portugal

Full list of author information is available at the end of the article
}

separable autoregressive model. The NIR-PLSR spectra were recorded using a Bruker equipment (vector $22 \mathrm{~N}$ model), and the calibration model to estimate pulp yield (RTIK16) was constructed using partial least-squares regression as implemented in with the QUANT2 software. DNA extraction and microsatellite genotyping were carried out as described in [1,2]. Linkage analysis and map construction were performed on independent male and female datasets using MAPMAKER/EXP ${ }^{\circledR} 3.0$ [3] under the $F_{2}$ backcross model. Framework maps with evenly distributed selected SSR and gene markers were used for QTL detection [4-8]. The selection of SSR markers took into consideration the possibility to establish synteny between available eucalypt maps in the literature. Interval Mapping and Multiple Interval Mapping QTL detection results were compared with the MultiQTL vs 2.6 software. QTL detection was repeated in data from 100 different simulations (using the $R$ software), after adding to the original phenotypes randomly selected values from a normal distribution with mean zero and a standard deviation that accounted for the reference essay error and the prediction error of the NIR calibration model.

\section{Results}

Many QTL for pulp yield related traits have been reported for every eucalypt chromosome, in the literature. There is insufficient mapping information to infer if these QTL where detected in similar genomic locations. In 6 of the 11 eucalypt linkage groups (LG2, LG4, LG5, LG6, LG9 and LG10), QTL for pulp yield related traits were detected in different species $(E$. globulus, E. grandis x E. urophylla and/or E. nitens) (Figure 1). RAIZ reports two verified QTL for pulp yield, in an E. globulus intraspecific cross, in linkage groups 3 and 11, detected in all simulations. Although 


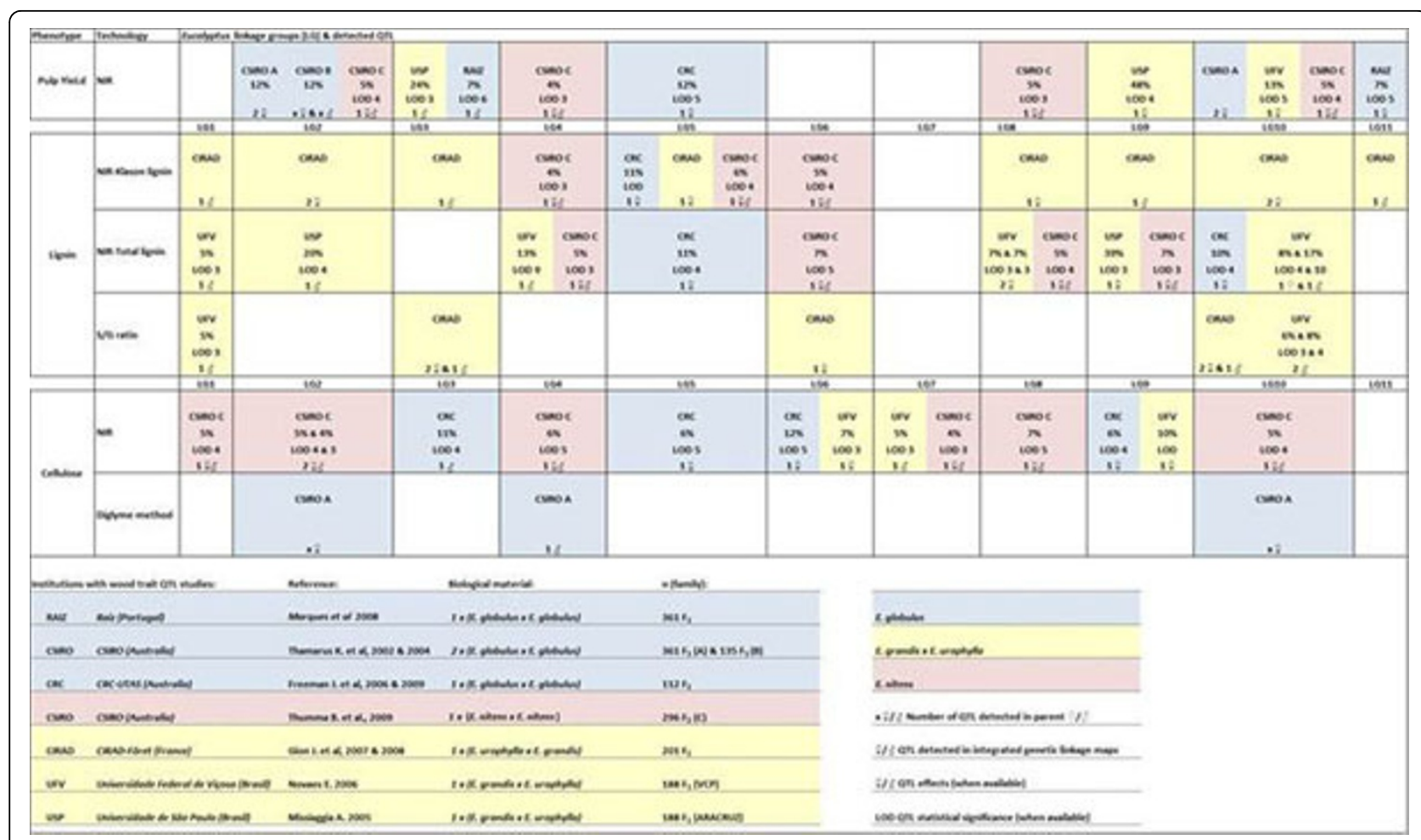

Figure 1 Raiz and literature QTL studies for pulp yield related traits in Eucalyptus, compared the linkage group (chromosome) level

these results can reflect the polygenic nature of the trait (as suggested by [9]) we cannot exclude the putative biases resulting from current limitations of existing studies in terms of experimental designs, phenotyping and/or data analysis.

\section{Conclusions}

QTL studies in some plant species have proved useful to target genomic regions for subsequent genomics investigation [10]. Forest trees experience a variety of environmental conditions and it is expected that some QTL will be age/environment specific and some will be consistently detected over multiple growing seasons. In order to raise the scope of inferences that can be drawn from QTL research in Eucalyptus and the prospects of delivering breeding tools from gene sequences, future QTL detection studies should account for experimental phenotyping error, in order to reduce putative false positive results, as we have done in RAIZ QTL detection experiment. Existing QTL mapping studies from different institutions could be upgraded in this perspective, in order to allow comparative mapping and the identification (or not) of specific genomic regions, detected in multiple pedigrees and environments, that could be explored further.

\section{Author details}

${ }^{1}$ RAIZ, Portugal. ${ }^{2} \mathrm{TTQB}$, Portugal. ${ }^{3} \mathrm{CBA} / \mathrm{DBA}$, FCUL, Portugal. ${ }^{4} \mathrm{CEF}$, ISA/UTL, Portugal. ${ }^{5}$ ICT, Portugal. ${ }^{6} \mathrm{DM}-\mathrm{CEMAT}$, IST/UTL, Portugal.

Published: 13 September 2011

\section{References}

1. Marques C, Vasquez-Kool J, Carocha V, Ferreira J, O'Malley D, Liu B, Sederoff R: Genetic dissection of vegetative propagation traits in Eucalyptus tereticornis and E. globulus. Theor Appl Genet 1999, 99:936-946.

2. Marques M, Brondani V, Grattapaglia D, Sederoff R: Conservation and synteny of SSR loci and QTLs for vegetative propagation in four Eucalyptus species. Theor Appl Genet 2002, 105(2-3):474-478.

3. Lander E, Green P, Abrahamson J, Barlow A, Daly M, Lincoln S, Newburg L: MAPMAKER: an interactive computer package for constructing primary genetic linkage maps of experimental and natural populations. Genomics 1987, 1:174-181.

4. Brondani R, Williams E, Brondani C, Grattapaglia D: A microsatellite-based consensus linkage map for species of Eucalyptus and a novel set of 230 microsatellite markers for the genus. Bmc Plant Biology 2006, 6(1):20.

5. Foucart C, Paux E, Ladouce N, San-Clemente H, Grima-Pettenati J, Sivadon P: Transcript profiling of a xylem vs phloem CDNA subtractive library identifies new genes expressed during xylogenesis in Eucalyptus. New Phytologist 2006, 170(4):739-752.

6. Paux E, Tamasloukht M, Ladouce N, Sivadon P, Grima-Pettenati J: Identification of genes preferentially expressed during wood formation in Eucalyptus. Plant Molecular Biology 2004, 55(2):263-280.

7. Rengel D, Clemente HS, Servant F, Ladouce N, Paux E, Wincker $P$, Couloux A, Sivadon P, Grima-Pettenati J: A new genomic resource dedicated to wood formation in Eucalyptus. Bmc Plant Biology 2009, 9.

8. Steane DA, Vaillancourt RE, Russell J, Powell W, Marshall D, Potts BM: Development and characterisation of microsatellite loci in Eucalyptus globulus (Myrtaceae). Silvae Genetica 2001, 50(2):89-91. 
9. Thumma BR, Southerton SG, Bell JC, Owen JV, Henery ML, Moran GF: Quantitative trait locus (QTL) analysis of wood quality traits in Eucalyptus nitens. Tree Genetics \& Genomes 2010, 6(2):305-317.

10. Price AH: Believe it or not, QTLs are accurate! Trends Plant Sci 2006, 11(5):213-216

doi:10.1186/1753-6561-5-S7-P48

Cite this article as: Marques et al.: Eucalypt pulp yield QTL from Raiz as compared to the literature. BMC Proceedings 2011 5(Suppl 7):P48.

Submit your next manuscript to BioMed Central and take full advantage of:

- Convenient online submission

- Thorough peer review

- No space constraints or color figure charges

- Immediate publication on acceptance

- Inclusion in PubMed, CAS, Scopus and Google Scholar

- Research which is freely available for redistribution 